\title{
Frequency and genotypes of Chlamydia trachomatis in patients attending the obstetrics and gynecology clinics in Jalisco, Mexico and correlation with sociodemographic, behavioral, and biological factors
}

Néstor Casillas-Vega', Rayo Morfín-Otero ${ }^{3}$, Santos García ${ }^{4}$, Jorge Llaca-Díaz ${ }^{1}$, Eduardo Rodríguez-Noriega ${ }^{3}$, Adrián Camacho-Ortiz ${ }^{5}$, Ma de la Merced Ayala-Castellanos ${ }^{3}$, Héctor J. Maldonado-Garza², Jesús Ancer-Rodríguez ${ }^{6}$, Guadalupe Gallegos-Ávila ${ }^{6}$, Alberto Niderhauser-García ${ }^{6}$ and Elvira Garza-González ${ }^{2^{*}}$ (D)

\begin{abstract}
Background: Chlamydia trachomatis is the causative agent of the most common bacterial sexually transmitted infection worldwide. The aim of this study was to investigate the frequency and genotypes of $C$. trachomatis in patients attending an obstetrics and gynecology clinic in Jalisco, Mexico and correlates them with sociodemographic, behavioral, and biological factors.

Methods: C. trachomatis detection was performed in endocervical samples from 662 patients by direct fluorescence assay (DFA) and two PCR assays that amplified the phospholipase D endonuclease superfamily protein (PLDESP) and OmpA genes. Positive samples were genotyped using PCR-restriction fragment length polymorphism assays. Sociodemographic, behavioral, and biological data were collected.

Results: The mean age of the study population was 31 (range, 14-78) years. C. trachomatis positivity was detected by DFA in $16.7 \%(n=111)$, PLDESP gene amplification in $14.2 \%(n=94)$, and OmpA gene amplification in $14.5 \%(n=96)$ of the population. Eight C. trachomatis genotypes were detected: E (39.6\%), F (29.2\%), D (15.6\%), K (6.3\%), L2 (3.1\%), G, J, and I (2.1\% each). C. trachomatis infection was associated with age, marital status, pregnancy, and hormonal contraceptive use (all $p=0.01$ ); intrauterine device use and previous premature birth (both $p=0.03$ ); and infection during pregnancy, previous ectopic pregnancy, pelvic inflammatory disease (PID), and green vaginal discharge (all $p=0.04)$. C. trachomatis genotype $\mathrm{K}$ was more likely to be detected in women histories of $\geq 2$ sexual partners, genotype $\mathrm{F}$ was more likely in pregnant women, genotype L2 was more likely in women with PID, genotype D was more likely in women who had had infection during previous pregnancies, and genotype E was more likely in those with previous ectopic pregnancies and green vaginal discharge (all $p=0.01$ ).

(Continued on next page)
\end{abstract}

\footnotetext{
* Correspondence: elvira_garza_gzz@yahoo.com

${ }^{2}$ Servicio de Gastroenterología, Hospital Universitario Dr. Jose Eleuterio

Gonzalez, Universidad Autónoma de Nuevo León, Av. Gonzalitos and

Madero, Mitras Centro PC, 64460 Monterrey, Nuevo León, Mexico

Full list of author information is available at the end of the article
} 
(Continued from previous page)

Conclusions: The frequency of $C$. trachomatis in our population was higher than previously reported worldwide, but within the range reported for Mexico. Genotype E was detected most frequently in the study population. Infection by C. trachomatis and C. trachomatis genotypes K, F, D, and E was strongly associated with multiple sociodemographic, behavioral, and biological factors. C. trachomatis genotype L2 was detected in women with PID.

Keywords: Chlamydia trachomatis, Genotype, Pregnancy, Mexico, Lymphogranuloma venereum

\section{Background}

Chlamydia trachomatis is the causative agent of the most common bacterial sexually transmitted infection (STI) worldwide [1], and the most frequently reported of all notifiable infections in the United States and Europe. In the United States alone, an estimated 2-5 million new cases of $C$. trachomatis infection occur each year [2, 3]. The infection is asymptomatic in almost $80 \%$ of women, and untreated genital infections lead to serious complications, such as pelvic inflammatory disease (PID) and infertility [4]. Asymptomatic infected people not only are at risk of developing serious long-term sequelae, but also transmit the infection. In these individuals, diagnosis of C. trachomatis infection is difficult because the pathogen load is low [5].

Nucleic acid amplification tests are the preferred method for the diagnosis of $C$. trachomatis genital infection because of their high sensitivity and specificity [4]. C. trachomatis typing is based on assays of the major outer membrane protein (MOMP). This analysis differentiates 18 genotypes based on changes in the single copy of the OmpA gene, which encodes the MOMP [6]. Genotypes A to $\mathrm{C}$ are associated with trachoma, genotypes $\mathrm{D}$ to $\mathrm{K}$ are associated with common urogenital and ocular pathogens in adults, and genotypes L1 to L3 are associated with lymphogranuloma venereum (LGV). In developed countries, genotypes D, E, and F are most commonly associated with genital infections [7-9].

Previous studies have documented C. trachomatis frequencies ranging from 1.5 to $28 \%$ in female populations in Mexico $[10,11]$. The only Mexican study that has included reporting on $C$. trachomatis genotypes showed that 24 of 152 (15.8\%) infertile patients were positive for C. trachomatis, and that the most prevalent genotype was F [12]. Thus, additional studies describing the frequency and genetic distribution of $C$. trachomatis in Mexico are needed. The aim of this study was to investigate the frequency and genotypes of $C$. trachomatis in patients attending the obstetrics and gynecology clinic of the Fray Antonio Alcalde Civil Hospital in Jalisco, Mexico and correlates them with Sociodemographic, behavioral, and biological factors.

\section{Methods}

\section{Ethics statement}

This study was performed with the approval of the Local Ethics Committee of the Hospital Civil de Guadalajara "Fray Antonio Alcalde" in Jalisco, Mexico (approval no. 062/13). Written informed consent was obtained from all patients or, for minors, from caretakers or guardians.

\section{Study population and data collection}

This was a cross-sectional study, conducted in the obstetrics and gynecology department of the Hospital Civil de Guadalajara "Fray Antonio Alcalde" from September 2013 to August 2014. Only patients attending the clinic for the first time were invited to participate. Sociodemographic and clinical data were collected for each patient.

\section{Specimen collection and DNA isolation}

Endocervical samples were collected using two sterile Dacron-tipped swabs and placed in 2-sucrose phosphate medium. Tubes were stored at $-20{ }^{\circ} \mathrm{C}$ until analyzed.

To obtain C. trachomatis DNA, one swab was subjected to enzymatic lysis with lysozyme and proteinase $\mathrm{K}$. Genomic DNA was extracted using a standard phenolchloroform-isoamyl alcohol protocol. The concentration and purity of the extracted DNA was evaluated through a spectrophotometer $\left(\right.$ GENESYS $^{\text {тм }}$ 20, Thermo Fisher Scientific, Germany).

\section{Direct fluorescence assay}

C. trachomatis was detected by direct fluorescence assay (DFA) using a monoclonal anti-Chlamydia antibody (BioMérieux, France). The endocervical samples were transferred to clean slides, which were incubated with fluorescent monoclonal antibody for $30 \mathrm{~min}$ at a controlled temperature of $25{ }^{\circ} \mathrm{C}$. The samples were observed under a fluorescence microscope (Axio Scope.A1; Zeiss, NY). Positive and negative controls were included in all assays.

\section{Phospholipase D Endonuclease Superfamily protein gene analysis}

Polymerase chain reaction (PCR) assays were performed to amplify the phospholipase D endonuclease superfamily 
(PLDESP) gene using the method described by Gimenes et al. [13] and amplify a fragment of 361 bp for about $60 \mathrm{~min}$. The total volume was $25 \mu \mathrm{L}$, consisting of $2.5 \mu \mathrm{L}$ 10× PCR buffer, $100 \mathrm{ng}$ DNA, $3 \mathrm{mM} \mathrm{MgCl}, 200 \mu \mathrm{M}$ of each deoxynucleotide triphosphate (dNTP), and $1 \mathrm{U}$ Taq polymerase (Bioline, London, UK). The primers used were CT-F (5'-TCTTTTTAAACCTCCGGAACCCACTT-3') and CT-R (5'-GGATGGCATCGCATAGCATTCTTTG$\left.3{ }^{\prime}\right)$. Each run was accompanied by positive and negative control sample. The thermocycler conditions were: $3 \mathrm{~min}$ at $94{ }^{\circ} \mathrm{C}$; then 35 cycles of $30 \mathrm{~s}$ at $94{ }^{\circ} \mathrm{C}, 30 \mathrm{~s}$ at $50{ }^{\circ} \mathrm{C}$, and $30 \mathrm{~s}$ at $72{ }^{\circ} \mathrm{C}$; and a final extension of $5 \mathrm{~min}$ at $72{ }^{\circ} \mathrm{C}$. The amplification products were visualized using electrophoresis on a $2.5 \%$ agarose gel stained with $1 \mu \mathrm{g} / \mathrm{mL}$ ethidium bromide, and compared with a standard (DNA Molecular Weight, Marker 100, Sigma Aldrich, St. Louis, MO, USA), and developed with a UV transilluminator (UVP BioImaging Systems Photodocumentator, Upland, CA).

\section{OmpA gene analysis and restriction fragment length polymorphism analysis}

The OmpA gene of C. trachomatis was amplified using the method described by Lan et al. [14] with small modifications, to amplify a fragment of $1100 \mathrm{bp}$ The total volume was $25 \mu \mathrm{L}$, consisting of $2.5 \mu \mathrm{L} 10 \times$ PCR buffer, 100 ng DNA, $3 \mathrm{mM} \mathrm{MgCl} 2,200 \mu \mathrm{M}$ of each dNTP, and $1 \mathrm{U}$ Taq polymerase (Bioline). The primers used were SERO1A (5' -ATGAAAAAACTCTTGAAATCGG-3') and SERO2A (5'-TTT CTA GAT CTT CAT TCT TGT $\left.\mathrm{T}-3^{\prime}\right)$. Each run was accompanied by positive and negative control sample. The thermocycler conditions were: $7 \mathrm{~min}$ at $94{ }^{\circ} \mathrm{C}$; then 40 cycles of $3 \mathrm{~min}$ at $95{ }^{\circ} \mathrm{C}, 3 \mathrm{~min}$ at $45{ }^{\circ} \mathrm{C}$, and $3 \mathrm{~min}$ at $72{ }^{\circ} \mathrm{C}$; and a final extension of $7 \mathrm{~min}$ at $72{ }^{\circ} \mathrm{C}$. The amplification products were visualized using electrophoresis on a $1.5 \%$ agarose gel stained with $1 \mu \mathrm{g} / \mathrm{mL}$ ethidium bromide, and compared with a standard (DNA Molecular Weight, Marker 1000, Sigma Aldrich, St. Louis, MO, USA), and developed with a UV transilluminator (UVP BioImaging Systems Photodocumentator, Upland, CA). Then, $0.5 \mu \mathrm{l}$ of the first-round PCR product was used for semi-nested PCR, which was performed with the same reagents and conditions except for the primers. The primers used for this assay were SERO2A and the nested primer PCTM3 (5'TCCTTGCAAGCTCTGCCTGTGGGGAATCCT-3').

The PCR products of the second round were analyzed using electrophoresis on a $1.5 \%$ agarose gel stained with $1 \mu \mathrm{g} / \mathrm{mL}$ ethidium bromide, and compared with a standard (DNA Molecular Weight, Marker 1000, Sigma Aldrich, St. Louis, MO, USA), and developed with a UV transilluminator (UVP BioImaging Systems Photodocumentator, Upland, CA). Positive samples were genotyped by $\mathrm{PCR}-$ restriction fragment length polymorphism (RFLP) assays, as described by Sayada et al. [15], using 1000-bp semi-nested PCR products. The nested PCR product $(10 \mu \mathrm{L})$ was digested with $2.5 \mathrm{U}$ Alu I (Promega, Madison, WI, USA) overnight at $37{ }^{\circ} \mathrm{C}$. Depending on the patterns obtained, the products were digested with the enzyme Hinf I (Promega). Genotypes were identified by their restriction patterns on ethidium bromidestained 3.5\% agarose gels. We used control DNA from the C. trachomatis strain ATCC VR-902B MOMP gene, partial cds (AmpliRun, ref. MBC012).

\section{Statistical analysis}

Descriptive analysis was performed. We used the Wilcoxon rank-sum test to compare mean values and Fisher's exact test or the chi-squared test to compare dichotomous variables. Analyses were performed using SPSS (version 18).

\section{Results}

Study population and patient characteristics

Of 30,000 female patients estimated who visited the obstetrics and gynecology department, 662 patients were enrolled in this study. Only patients who agreed to participate and were attending the clinic for the first time were included. The mean age of the study population was 31 (range, 14-78) years. The largest proportion $(38.5 \%, n=255)$ of patients was aged $20-29$ years. Most (75.5\%, $n=500)$ patients were married or living with a partner, and $37.6 \%(n=249)$ reported using condoms as a contraceptive method. The majority $(69.5 \%, n=460)$ of patients were housewives, and $43.3 \%(n=287)$ were pregnant at the time of sample collection (Table 1).

\section{Detection of infection}

C. trachomatis positivity was detected by DFA in $16.7 \%$ ( $n=111)$ of the study population, by PLDESP gene amplification in $14.2 \%(n=94)$, and by $O m p A$ gene amplification in $14.5 \%(n=96)$ of the population. According to PCR-RFLP results, the most frequent OmpA genotype corresponded to $\mathrm{E}(39.6 \%, n=38)$, followed by $\mathrm{F}(29.2 \%$, $n=28), \mathrm{D}(15.6 \%, n=15), \mathrm{K}(6.3 \%, n=6)$, and $\mathrm{L} 2$ $(3.1 \%, n=3)$. Genotypes G, I, and J were detected less frequently $(2.1 \%, n=2$ each; Table 2$)$. Final results were regarded as true positives if the semi-nested PCR was positive (gold standard). The overall agreement of DFA results with semi-nested PCR the validation parameters were as follows: sensitivity $96 \%$, specificity $97.3 \%$, negative predictive value $99.3 \%$, positive predictive value $86.5 \%$, and accuracy $97.3 \%$. Comparing the PCR results of the PLDESP gene with semi-nested PCR the validation parameters were as follows: sensitivity $98.6 \%$, specificity $100 \%$, negative predictive value $99.6 \%$, positive predictive value $100 \%$, and accuracy $99.7 \%$. 
Table 1 Associations of C. trachomatis with sociodemographic, behavioral, biological factors and specific symptoms of the study population

\begin{tabular}{|c|c|c|c|c|}
\hline Characteristic & $\begin{array}{l}\text { Total positive population } \\
{[n(\%), n=662]}\end{array}$ & $\begin{array}{l}\text { C. trachomatis positive by OmpA } \\
{[n(\%), n=96]}\end{array}$ & $P$ & $\begin{array}{l}\text { Adjusted OR } \\
(95 \% \mathrm{Cl})\end{array}$ \\
\hline \multicolumn{5}{|l|}{ SOCIODEMOGRAPHIC FACTORS } \\
\hline \multicolumn{5}{|l|}{ Age group (years) } \\
\hline $14-19$ & $93(14)$ & $10(10.4)$ & 0.14 & $0.68(0.32,1.33)$ \\
\hline $20-29$ & $255(38.5)$ & $35(36.5)$ & 0.32 & $0.90(0.57,1.41)$ \\
\hline $30-39$ & $186(28.1)$ & $23(24)$ & 0.16 & $0.77(0.46,1.27)$ \\
\hline$\geq 40$ & $129(19.5)$ & $28(29.2)$ & 0.01 & $2.69(1.61,4.44)$ \\
\hline \multicolumn{5}{|l|}{ Occupation } \\
\hline Housewife & $460(69.5)$ & $64(66.7)$ & 0.26 & $0.85(0.53,1.32)$ \\
\hline Employee/merchant & $106(16)$ & 19 (19.8) & 0.13 & $1.37(0.77,2.36)$ \\
\hline Professional & $63(9.5)$ & $8(8.3)$ & 0.34 & $0.84(0.36,1.77)$ \\
\hline Student & $33(5)$ & $5(5.2)$ & 0.43 & $1.05(0.35,2.66)$ \\
\hline \multicolumn{5}{|l|}{ Marital status } \\
\hline Single & $140(21.2)$ & $4(4.2)$ & 0.43 & $1.05(0.32,2.61)$ \\
\hline Divorced/widowed/separated & $22(3.3)$ & $8(8.3)$ & 0.34 & $0.84(0.36,1.77)$ \\
\hline Married/living with partner & $500(75.5)$ & $83(86.5)$ & 0.01 & $1.99(1.10,3.83)$ \\
\hline \multicolumn{5}{|l|}{ BEHAVIORAL FACTORS } \\
\hline Alcohol use & $145(21.9)$ & $23(24)$ & 0.31 & $1.12(0.69,1.77)$ \\
\hline Current smoker & $200(30.21)$ & $31(32.3)$ & 0.29 & $1.14(0.67,1.89)$ \\
\hline \multicolumn{5}{|l|}{ Age at first intercourse (years) } \\
\hline$<18$ & $330(49.9)$ & $47(49)$ & 0.43 & $0.96(0.62,1.49)$ \\
\hline$\geq 18$ & $332(50.2)$ & $49(51)$ & 0.17 & $1.23(0.79,1.91)$ \\
\hline \multicolumn{5}{|l|}{ No. of sex partners } \\
\hline 0 & $7(1)$ & $2(2.1)$ & 0.16 & $2.38(0.31,12.27)$ \\
\hline 1 & $311(47)$ & $40(41.7)$ & 0.13 & $0.77(0.49,1.20)$ \\
\hline $2-4$ & $279(42.2)$ & $43(44.8)$ & 0.28 & $1.13(0.73,1.75)$ \\
\hline$\geq 5$ & $65(9.8)$ & $11(11.5)$ & 0.27 & $1.22(0.59,2.38)$ \\
\hline \multicolumn{5}{|l|}{ Contraceptive use } \\
\hline Hormonal & $102(15.4)$ & $7(7.3)$ & 0.01 & $0.39(0.16,0.38)$ \\
\hline Condom & $249(37.6)$ & $39(40.6)$ & 0.25 & $1.16(0.74,1.82)$ \\
\hline IUD & $67(10.1)$ & 15 (15.6) & 0.03 & $1.79(0.93,3.28)$ \\
\hline Bilateral tubal occlusion & $40(6)$ & $5(5.2)$ & 0.37 & $0.83(0.28,2.06)$ \\
\hline None & $204(30.8)$ & $39(40.6)$ & 0.02 & $1.55(0.99,2.42)$ \\
\hline \multicolumn{5}{|l|}{ BIOLOGICAL FACTORS } \\
\hline Pregnant at sampling & $287(43.3)$ & $31(32.3)$ & 0.01 & $0.57(0.36,0.91)$ \\
\hline Previous pregnancy & $621(93.8)$ & $88(91.7)$ & 0.19 & $0.70(0.32,1.67)$ \\
\hline \multicolumn{5}{|l|}{ Complications of previous pregnancy } \\
\hline Infection & $386(58.3)$ & $49(51)$ & 0.04 & $0.69(0.44,1.07)$ \\
\hline Bleeding & $69(10.4)$ & $10(10.4)$ & 0.48 & $0.99(0.46,1.97)$ \\
\hline Risk of spontaneous abortion & $116(17.5)$ & $15(15.6)$ & 0.31 & $0.85(0.45,1.51)$ \\
\hline Premature birth & $50(7.5)$ & $12(12.5)$ & 0.03 & $1.98(0.96,3.88)$ \\
\hline Ectopic pregnancy & $9(1.35)$ & $4(4.1)$ & 0.03 & $3.46(0.87,12.19)$ \\
\hline Previous abortion & $163(24.6)$ & $26(27.1)$ & 0.25 & $1.17(0.71,1.90)$ \\
\hline
\end{tabular}


Table 1 Associations of C. trachomatis with sociodemographic, behavioral, biological factors and specific symptoms of the study population (Continued)

\begin{tabular}{|c|c|c|c|c|c|}
\hline$\overline{P I D}$ & & $295(44.5)$ & $36(37.5)$ & 0.04 & $0.68(0.32,1.33)$ \\
\hline \multicolumn{6}{|c|}{ Dyspareunia } \\
\hline & Pain /burning & $222(33.5)$ & $27(28.1)$ & 0.11 & $0.74(0.45,1.19)$ \\
\hline & Bleeding & $28(4.2)$ & $3(3.1 \%)$ & 0.3 & $0.69(0.16,2.14)$ \\
\hline \multicolumn{6}{|c|}{ Vaginal discharge } \\
\hline \multicolumn{6}{|c|}{ Amount } \\
\hline & Scarce & $101(15.2)$ & $16(16.7)$ & 0.33 & $1.13(0.61,2.00)$ \\
\hline & Moderate & $322(48.6)$ & 44 (45.8) & 0.27 & $0.87(0.56,1.35)$ \\
\hline & Copious & $185(27.9)$ & $26(27.1)$ & 0.42 & $0.95(0.57,1.53)$ \\
\hline \multicolumn{6}{|l|}{ Color } \\
\hline & White & $450(68)$ & $65(67.7)$ & 0.47 & $0.98(0.62,1.58)$ \\
\hline & Yellow & $194(29.3)$ & $24(25)$ & 0.15 & $0.77(0.46,1.27)$ \\
\hline & Green & $45(6.8)$ & $11(11.5)$ & 0.04 & $1.90(0.89,3.81)$ \\
\hline & Brown & $19(2.8)$ & $5(5.2)$ & 0.47 & $0.98(0.62,1.58)$ \\
\hline \multicolumn{6}{|c|}{ Previous infection } \\
\hline & Urinary & $188(28.4)$ & $23(24)$ & 0.14 & $0.76(0.45,1.25)$ \\
\hline & Vaginal & $420(63.4)$ & $58(60.4)$ & 0.25 & $0.86(0.55,1.34)$ \\
\hline
\end{tabular}

$O R$ odds ratio, $C I$ confidence interval, IUD Intrauterine Device, PID pelvic inflammatory disease

\section{Association of C. trachomatis infection with sociodemographic, behavioral, biological factors, and specific symptoms}

C. trachomatis infection was associated with age $\geq 40$ years, being married or living with a partner, and the use of hormonal contraceptives (all $p=0.01$ ), as well as intrauterine device (IUD) use $(p=0.03)$ and no history of birth control use $(p=0.02)$. In addition, pregnant women $(p=0.01)$ and those who had had infections during pregnancy $(p=0.04)$ were more likely to be infected. Infected women were more likely to have previous histories of giving birth prematurely $(\mathrm{p}=0.03)$, ectopic pregnancy, PID, or green vaginal discharge (all $p=0.04$; Table 1).

\section{Association of C. trachomatis genotypes with risk factors, and specific symptoms}

Women with histories of two or more sexual partners were more likely to be infected with $C$. trachomatis genotype $\mathrm{K}(p=0.01)$, whereas pregnant women were more likely to be infected with $C$. trachomatis genotype $\mathrm{F}(p=0.03)$. Associations were detected between genotype F, L2 is associated with PID $(p=0.02)$, genotype D and infection during previous pregnancy $(p=0.02)$, and genotype $\mathrm{E}$ was associated with previous ectopic pregnancy $(p=0.04)$ and green vaginal discharge $(p=001$; Table 2). We found no association of any C. trachomatis genotype with previous pregnancy, abortion, premature birth and specific symptoms (data not shown).

\section{Discussion}

C. trachomatis is a causal factor of STI, the course of which is frequently asymptomatic. In this study, the frequency and genotypes of $C$. trachomatis in patients attending a gynecology clinic in the largest public hospital in the state of Jalisco were determined. To our knowledge, this work is the largest molecular epidemiological study of $C$. trachomatis frequency and genotypes in Mexico, and their associations with sociodemographic, behavioral, and biological factors.

The frequency of C. trachomatis detected by PCR in this study was $14.5 \%$. Previous studies in Mexican populations have detected $C$. trachomatis at frequencies ranging from $1.5 \%$ to $28 \%[10,11]$. Our results thus fall within the reported range for Mexico. The frequency detected in the current study was higher than reported for Australia (4.9\%) [16, 17], Spain (4\%) [17], France (3.6\%) [18], and the United Kingdom (3\%) [19].

Current guidelines from the Centers for Disease Control and Infection recommend annual screening for this bacteria in sexually active women aged $\leq 25$ years and in those aged $>25$ years who are at risk of infection [20]. In Mexico, C. trachomatis infection is not a notifiable disease; thus, routine testing is not mandatory. This situation makes the collection of reliable epidemiological data from throughout the country difficult.

The prevalence of $C$. trachomatis genotypes has been determined for several countries, but little such data are available for Latin America. In our study, the most frequent genotype was E (39.6\%), followed by F (29.2\%) 


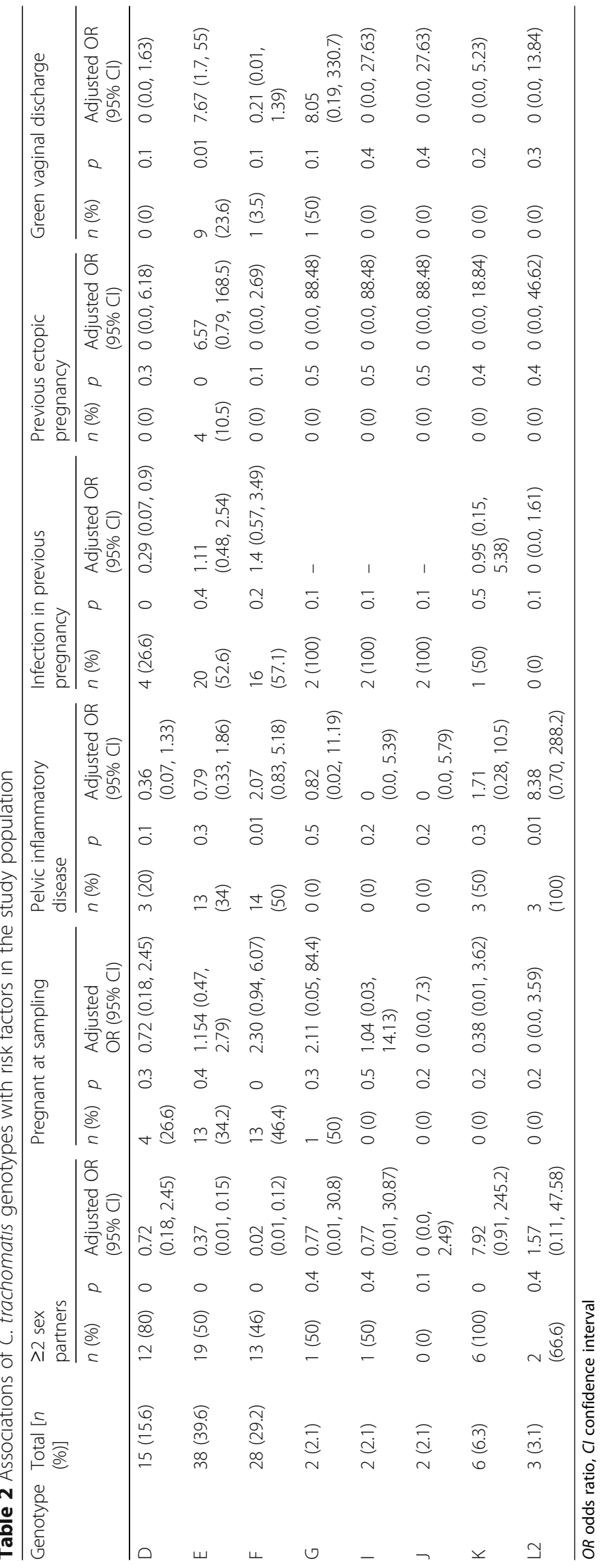


and D (15.6\%). In a previous study of C. trachomatis in Mexico, genotype $\mathrm{F}$ was most frequent $(54.2 \%)$, followed by genotypes $\mathrm{E}, \mathrm{G}, \mathrm{K}$, and $\mathrm{L} 2$ (8.7\% each); genotypes $\mathrm{D}$, $\mathrm{F}$, and I were detected at a frequency of $4.2 \%$ each [12]. That study, however, involved the examination of only 152 samples from infertile women (with only 24 specimens positive for $C$ trachomatis), and limited clinical data were reported that contrasted with our results, this may be due to the small sample analyzed by the previous study [12]. Our results are similar to those reported from other Latin America and other parts of the world. In a Brazilian study that included 141 women, the most frequent genotype detected was E (39.7\%), followed by $\mathrm{F}$ (17.7\%) and D (17\%) [21]. In a Costa Rican study including 806 C. trachomatis-positive samples, genotype E was also most frequent (31\%), followed by $\mathrm{F}$ and D (21\% each) [22]. Genotype $\mathrm{E}$ was most frequent in a study including 81 women conducted in Argentina [23]. Similar frequencies have been reported in other parts of the world, including the Netherlands (E, 41.5\%; F, 21.8\%; D, 11.9\%) [24], China (E, 37.2\%; F, 31.3\%) [25], and Alabama, United States (E, 29\%; F and D, 19\% each) [26].

In our population, genotype L2 was identified in three patients with no clinical data of LGV. This situation has been described previously in Mexico [12]. LGV is a sexually transmitted disease caused by $C$. trachomatis serotypes L1, L2, and L3. It probably affects both sexes equally, although it has been reported more frequently in men, in whom the early manifestations of the disease are more evident. Men often display the acute form of LGV, whereas it is often detected in women when latestage complications develop [27]. Most cases in Europe and North America have been identified in men who have sex with men [28]. A small number of genotype L cases has been reported in heterosexuals in the United Kingdom and Europe, including seven women in the UK since 2004, but these cases appear to be linked to male bisexual partners or sexual contact with those returning from endemic areas [29].

Interestingly, patients who were married or living with a partner were most at risk of infection with C. trachomatis in the present study. This finding may be explained by the lack of contraceptive use or infection prevention in this population.

An association of hormonal contraceptive use with the risk of infection was detected in the present study, confirming the results of previous studies [30]. Hormonal contraception is associated with an increased rate of cervical colonization because estrogen supports bacterial growth [31].

Recent studies have shown that IUD use is safe for all women, including those at high risk of STIs [32]. In this study, patients using IUDs were more likely to be infected with $C$. trachomatis than were those who did not report IUD use, possibly due to the trauma caused by IUDs.

Of special concern is the strong association between C. trachomatis infection and pregnancy at the time of sampling. Prompt diagnosis in this population is a cornerstone for the prevention of infection in newborns [33].

In the current study, C. trachomatis infection was associated with PID. Several studies have demonstrated that women who test positive for C. trachomatis have an increased risk of PID throughout their reproductive life compared with women who test negative [34, 35]. PID has also been suggested to be associated with an increased risk of repeated infection [36].

Possible associations of $C$. trachomatis genotypes with specific clinical symptoms or the pathogenicity of the disease have not been described completely. In a previous study, $C$. trachomatis genotype $\mathrm{K}$ was associated with vaginal discharge [37]; in our sample, genotype $\mathrm{K}$ was detected more frequently in patients with multiple partners. Furthermore, genotype F was detected more frequently in pregnant women. C. trachomatis genotype $\mathrm{F}$ has been associated with reduced mucopurulent endocervical discharge [38] and inflammation in men, but not in women [39]. Women who reported abdominal pain were more likely to be infected with genotype $\mathrm{F}$ [40]. In this study, genotype $E$ was associated with previous ectopic pregnancy and green vaginal discharge. In a previous study, genotype $\mathrm{E}$ was associated with conjunctivitis in neonates [23].

\section{Conclusion}

To our knowledge, this study is the only molecular epidemiological research to date on the frequency and genotypes of $C$. trachomatis, and their associations with sociodemographic, behavioral, and biological factors, in women attending a gynecology and obstetrics clinic in Mexico. This is a preliminary report and should be done in a much larger cohort, with a greater number of positive samples for Chlamydia. The frequency of $C$. trachomatis in our population was higher than previously reported worldwide, but within the range reported for Mexico. Genotype E was detected most frequent in the study population.

\section{Abbreviations}

Cl: Confidence interval; DFA: Direct fluorescence assay; dNTP: Doxynucleotide triphosphate; IUD: Intrauterine device; LGV: Lymphogranuloma venereum; MOMP: Major outer membrane protein; OR: Odds ratio; PCR: Polymerase chain reaction; PID: Pelvic inflammatory disease; PLDESP: Phospholipase D endonuclease superfamily protein; RFLP: Restriction Fragment Length Polymorphism Analysis; STI: Sexually transmitted infection

\section{Acknowledgements}

The authors would like to thank the study participants and our research team Acevedo-Duarte L, González-Guzmán M, Martínez-Macías SK, JiménezGutiérrez C, Carbajal-Rimoldi A. for all his contributions in the research. 


\section{Funding}

The authors declare that there is no economic, personal, political or academic relation that could influence our judgment. In particular, we have not received any benefit in cash or kind, any hospitality, or any subsidy derived from any source that may have or be perceived to have an interest in the outcome of the manuscript.

\section{Availability of data and materials}

All data generated or analyzed during this study are included in this published article.

\section{Authors' contributions}

NCV conceived of the study, participated in the design of the study, carried out the direct immunofluorescence methods and molecular studies, performed the statistical analysis and drafted the manuscript. RMO conceived of the study, participated in its design and coordination of the study, interpretation of data clinical and drafted the manuscript. SG conceived of the study, and participated in its design and coordination of the study. JLD participated in developing methods of direct immunofluorescence. ERN conceived of the study, and participated in its design and coordination of the study. ACO participated in its design and drafted the manuscript. MMAC conducted taking the samples, performed the medical records. HJMG conceived of the study and drafted the manuscript. JAR conceived and participated of the study. GGA participated in the design of the study. ANG participated in the design of the study. EGG conceived of the study, participated in its design and coordination of the study, carried out the direct immunofluorescence methods and molecular studies, performed the statistical analysis and drafted the manuscript. All authors read and approved the final manuscript.

\section{Ethics approval and consent to participate}

This study was performed with the approval of the Local Ethics Committee of the Hospital Civil de Guadalajara "Fray Antonio Alcalde" in Jalisco, Mexico (approval no. 062/13). Written informed consent was obtained from all patients or, for minors, from caretakers or guardians.

\section{Consent for publication}

Not applicable, there are no images or details on individuals reported within the manuscript.

\section{Competing interests}

The authors declare that they have no competing interests.

\section{Publisher's Note}

Springer Nature remains neutral with regard to jurisdictional claims in published maps and institutional affiliations.

\section{Author details \\ ${ }^{1}$ Departamento de Patología Clínica, Hospital Universitario Dr. Jose Eleuterio Gonzalez, Universidad Autónoma de Nuevo León, Monterrey, Nuevo León, Mexico. ${ }^{2}$ Servicio de Gastroenterología, Hospital Universitario Dr. Jose Eleuterio Gonzalez, Universidad Autónoma de Nuevo León, Av. Gonzalitos and Madero, Mitras Centro PC, 64460 Monterrey, Nuevo León, Mexico. ${ }^{3}$ Hospital Civil de Guadalajara, Fray Antonio Alcalde, y el Instituto de Patología Infecciosa y Experimental, Centro Universitario de Ciencias de la Salud, Universidad de Guadalajara, Guadalajara, Jalisco, Mexico. \\ ${ }^{4}$ Departamento de Microbiología e Inmunología, Facultad de Ciencias Biológicas Universidad Autónoma de Nuevo León, San Nicolás, Nuevo León, Mexico. ${ }^{5}$ Coordinación de Epidemiología Hospitalaria, Hospital Universitario Dr. Jose Eleuterio Gonzalez, Universidad Autónoma de Nuevo León, Monterrey, Mexico. ${ }^{6}$ Departamento de Patología, Facultad de Medicina, Universidad Autónoma de Nuevo León, Monterrey, Nuevo León, Mexico.}

\section{Received: 7 September 2015 Accepted: 18 August 2017} Published online: 15 September 2017

\section{References}

1. Bender N, Herrmann B, Andersen B, Hocking JS, van Bergen J, et al. Chlamydia infection, pelvic inflammatory disease, ectopic pregnancy and infertility: crossnational study. Sex Transm Infect. 2011;87:601-8.
2. European Centre for Disease Prevention and Control. Sexually transmitted infections in Europe 2013. Stockholm: ECDC; 2015.

3. Workowski KA, \& Berman SM. Centers for Disease Control and Prevention sexually transmitted disease treatment guidelines. Clinical infectious diseases. 2011;53(suppl_3):S59-S63.

4. Semeniuk H, Zentner A, Read R, Church D. Evaluation of sequential testing strategies using non-amplified and amplified methods for detection of Chlamydia trachomatis in endocervical and urine specimens from women. Diagn Microbiol Infect Dis. 2002;42:43-51.

5. Stamm WE. Chlamydia trachomatis infections: progress and problems. J Infect Dis. 1999;179(Suppl 2):S380-3.

6. Rodriguez $P$, de Barbeyrac B, Persson $K$, Dutilh B, Bebear C. Evaluation of molecular typing for epidemiological study of Chlamydia trachomatis genital infections. J Clin Microbiol. 1993;31:2238-40.

7. Kapil R, Press CG, Hwang ML, Brown L, Geisler WM. Investigating the epidemiology of repeat Chlamydia trachomatis detection after treatment by using C. trachomatis OmpA genotyping. J Clin Microbiol. 2015:53:546-9.

8. Kese D, Potocnik M, Maticic M, Kogoj R. Genotyping of Chlamydia trachomatis directly from urogenital and conjunctiva samples using an ompA gene pyrosequencing-based assay. FEMS Immunol Med Microbiol. 2011;63:210-6.

9. Taheri Beni B, Jenab A, Roghanian R, Motamedi H, Golbang N, et al. Genotyping of Endocervical Chlamydia trachomatis strains and detection of serological markers of acute and chronic inflammation in their host. Int J Fertil Steril. 2012;6:101-6.

10. Guerra-Infante F, Flores-Medina S, Arteaga-Troncoso G, Zamora-Ruiz A Lopez-Hurtado M, et al. Risk factors and reproductive sequelae associated with Chlamydia trachomatis infection in infertile women. Salud Publica Mex. 2003:45(Supp 5):S672-80.

11. Esquivel CA, Briones Ezcarzaga ML, Castruita Limones DE, Lazalde Ramos BP, Salas EV, et al. Prevalence of Chlamydia trachomatis infection in registered female sex workers in northern Mexico. Sex Transm Dis. 2003;30:195-8.

12. de Jesus De Haro-Cruz M, Deleon-Rodriguez I, Escobedo-Guerra MR, LopezHurtado M, Arteaga-Troncoso G, et al. Genotyping of Chlamydia trachomatis from endocervical specimens of infertile Mexican women. Enfermedades infecciosas y microbiologia clinica. 2011;29:102-8.

13. Gimenes F, Medina FS, Abreu AL, Irie MM, Esquicati IB, et al. Sensitive simultaneous detection of seven sexually transmitted agents in semen by multiplex-PCR and of HPV by single PCR. PLoS One. 2014;9:e98862.

14. Lan J, Walboomers JM, Roosendaal R, van Doornum GJ, MacLaren DM, et al. Direct detection and genotyping of Chlamydia trachomatis in cervical scrapes by using polymerase chain reaction and restriction fragment length polymorphism analysis. J Clin Microbiol. 1993;31:1060-5.

15. Sayada C, Denamur E, Orfila J, Catalan F, Elion J. Rapid genotyping of the Chlamydia trachomatis major outer membrane protein by the polymerase chain reaction. FEMS Microbiol Lett. 1991;67:73-8.

16. Walker J, Fairley CK, Bradshaw CS, Tabrizi SN, Chen MY, et al. The difference in determinants of Chlamydia trachomatis and Mycoplasma genitalium in a sample of young Australian women. BMC Infect Dis. 2011:11-35.

17. Fernandez-Benitez C, Mejuto-Lopez P, Otero-Guerra L, Margolles-Martins MJ, Suarez-Leiva P, et al. Prevalence of genital Chlamydia trachomatis infection among young men and women in Spain. BMC Infect Dis. 2013;13:388.

18. Goulet V, de Barbeyrac B, Raherison S, Prudhomme M, Semaille C, et al. Prevalence of Chlamydia trachomatis: results from the first national population-based survey in France. Sex Transm Infect. 2010:86:263-70.

19. Fenton KA, Korovessis C, Johnson AM, McCadden A, McManus S, et al. Sexual behaviour in Britain: reported sexually transmitted infections and prevalent genital Chlamydia trachomatis infection. Lancet. 2001;358:1851-4.

20. Workowski KA, Berman S (2010) Sexually transmitted diseases treatment guidelines, 2010. MMWR Recommendations and reports: Morbidity and mortality weekly report Recommendations and reports/Centers for Disease Control 59: 1-110.

21. Machado AC, Bandea Cl, Alves MF, Joseph K, Igietseme J, et al. Distribution of Chlamydia trachomatis genovars among youths and adults in Brazil. J Med Microbiol. 2011;60:472-6.

22. Quint K, Porras C, Safaeian M, Gonzalez P, Hildesheim A, et al. Evaluation of a novel PCR-based assay for detection and identification of Chlamydia trachomatis serovars in cervical specimens. J Clin Microbiol. 2007;45:3986-91.

23. Gallo Vaulet L, Entrocassi C, Corominas Al, Rodriguez Fermepin M. Distribution study of Chlamydia trachomatis genotypes in symptomatic 
patients in Buenos Aires, Argentina: association between genotype $\mathrm{E}$ and neonatal conjunctivitis. BMC Res Notes. 2010;3:34.

24. Morre SA, Ossewaarde JM, Savelkoul PH, Stoof J, Meijer CJ, et al. Analysis of genetic heterogeneity in Chlamydia trachomatis clinical isolates of serovars $\mathrm{D}, \mathrm{E}$, and $\mathrm{F}$ by amplified fragment length polymorphism. J Clin Microbiol. 2000;38:3463-6.

25. Gao X, Chen XS, Yin YP, Zhong MY, Shi MQ, et al. Distribution study of Chlamydia trachomatis serovars among high-risk women in China performed using PCR-restriction fragment length polymorphism genotyping. J Clin Microbiol. 2007;45:1185-9.

26. Geisler WM, Suchland RJ, Stamm WE. Association of Chlamydia trachomatis Serovar la infection with black race in a sexually transmitted diseases clinic patient population in Birmingham, Alabama. Sex Transm Dis. 2006;33:621-4.

27. Ceovic R, Gulin SJ. Lymphogranuloma venereum: diagnostic and treatment challenges. Infection and drug resistance. 2015;8:39-47.

28. Ward H, Alexander S, Carder C, Dean G, French P, et al. The prevalence of lymphogranuloma venereum infection in men who have sex with men: results of a multicentre case finding study. Sex Transm Infect. 2009;85:173-5.

29. Ward H, Martin I, Macdonald N, Alexander S, Simms I, et al. Lymphogranuloma venereum in the United kingdom. Clin Infect Dis. 2007;44:26-32.

30. Mohllajee AP, Curtis KM, Martins SL, Peterson HB. Hormonal contraceptive use and risk of sexually transmitted infections: a systematic review. Contraception. 2006;73:154-65.

31. Hart G. Risk profiles and epidemiologic interrelationships of sexually transmitted diseases. Sex Transm Dis. 1993;20:126-36.

32. Birgisson NE, Zhao Q, Secura GM, Madden T, Peipert JF. Positive testing for Neisseria gonorrhoeae and Chlamydia trachomatis and the risk of pelvic inflammatory disease in IUD users. J Women's Health. 2015;24:354-9.

33. Borborema-Alfaia AP, Freitas NS, Astolfi Filho S, Borborema-Santos CM. Chlamydia trachomatis infection in a sample of northern Brazilian pregnant women: prevalence and prenatal importance. Braz I Infect Dis. 2013;17:545-50.

34. Bakken IJ, Ghaderi S. Incidence of pelvic inflammatory disease in a large cohort of women tested for Chlamydia trachomatis: a historical follow-up study. BMC Infect Dis. 2009;9:130.

35. Low N, Egger M, Sterne JA, Harbord RM, Ibrahim F, et al. Incidence of severe reproductive tract complications associated with diagnosed genital chlamydial infection: the Uppsala Women's cohort study. Sex Transm Infect. 2006;82:212-8

36. Haggerty CL, Gottlieb SL, Taylor BD, Low N, Xu F, et al. Risk of sequelae after Chlamydia trachomatis genital infection in women. J Infect Dis. 2010; 201(Suppl 2):S134-55.

37. Morre SA, Rozendaal L, van Valkengoed IG, Boeke AJ, van Voorst Vader PC, et al. Urogenital Chlamydia trachomatis serovars in men and women with a symptomatic or asymptomatic infection: an association with clinical manifestations? J Clin Microbiol. 2000;38:2292-6.

38. Workowski KA, Stevens CE, Suchland RJ, Holmes KK, Eschenbach DA, et al. Clinical manifestations of genital infection due to Chlamydia trachomatis in women: differences related to serovar. Clin Infect Dis. 1994;19:756-60.

39. van de Laar MJ, van Duynhoven YT, Fennema JS, Ossewaarde JM, van den Brule AJ, et al. Differences in clinical manifestations of genital chlamydial infections related to serovars. Genitourin Med. 1996;72:261-5.

40. Geisler WM, Suchland RJ, Whittington WL, Stamm WE. The relationship of serovar to clinical manifestations of urogenital Chlamydia trachomatis infection. Sex Transm Dis. 2003;30:160-5.

\section{Submit your next manuscript to BioMed Central and we will help you at every step:}

- We accept pre-submission inquiries

- Our selector tool helps you to find the most relevant journal

- We provide round the clock customer support

- Convenient online submission

- Thorough peer review

- Inclusion in PubMed and all major indexing services

- Maximum visibility for your research

Submit your manuscript at www.biomedcentral.com/submit

) Biomed Central 